\title{
India: Enhancing girls' life skills requires long-term commitment
}

Frontiers in Reproductive Health

Follow this and additional works at: https://knowledgecommons.popcouncil.org/departments_sbsr-rh How does access to this work benefit you? Let us know!

\section{Recommended Citation}

"India: Enhancing girls' life skills requires long-term commitment," FRONTIERS OR Summary. Washington, DC: Population Council, 2005. 


\section{India \\ Youth}

OR Summary 53

\section{Enhancing Girls' Life Skills Requires Long-term Commitment}

Indian girls and their parents welcomed a program providing vocational training and savings schemes. However, few girls turned their new skills into economic gain, in part due to social barriers that impede girls' access to economic markets. Vocational training programs should take a long-term approach to facilitate partnerships with parents and communities in support of adolescent girls' economic participation.

\section{Background}

While adolescents in India face a rapidly changing economic environment, the choices available to unmarried girls are very different from those available to boys. Girls are much less likely than boys to remain unmarried into their twenties, complete middle school, or generate income. Due to social norms, they have limited control over their life choices, and are less likely than boys to be allowed mobility within or beyond their immediate community.

\section{In 2001, the Population Council teamed with} CARE India to test a pilot intervention to enhance skills and expand life choices for adolescent girls living in the slums of Allahabad. The 10-month intervention, which was incorporated into CARE's ongoing reproductive health program for slum dwellers, tested the effect of the skills intervention on the girls' reproductive health knowledge, social contacts and mobility, selfesteem, and perception of gender roles.

The quasi-experimental design compared pre- and post-intervention changes among girls aged $14-$ 19 in the intervention site with a similar population in a control site. Adolescents in both sites received reproductive health education from peer educators. In addition, participants in the experimental area received courses on such skills as embroidery, pottery decoration, and candlemaking, help with the establishment of savings accounts, and follow-up counseling. A total of 19 courses, most lasting one to two weeks, were

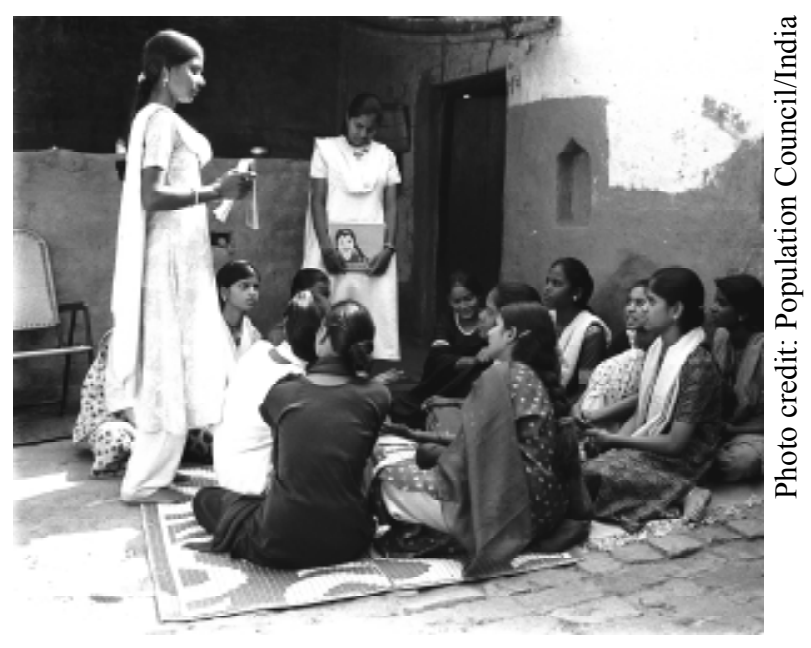

conducted at the homes of peer educators and in training centers outside the slum. The impacts of the intervention were assessed using survey responses from girls who were interviewed in both baseline and endline surveys.

\section{Findings}

Girls and their parents found the life skills training acceptable, but the intervention had little overall impact. This was partly due to its short duration and also to social barriers that would have to be addressed in any economic programs for youth. The greatest impacts were visible in those indicators that directly corresponded to the intervention, as follows:

- Knowledge of reproductive health increased significantly in the experimental site relative to the control site. Knowledge about basic reproductive health questions (based on an eight- 
point index) increased from 4.0 to 6.7 in the experimental group, while increasing modestly from 4.3 to 5.8 in the control group. This could be due to the increased time that girls in the experimental group spent with peers, affording time to discuss the course material.

- The intervention had a statistically significant positive impact on girls' membership in groups. The proportion of girls knowing a safe place for meeting other girls outside the home (usually at the home of the peer educator) increased from 17 percent to 83 percent in the experimental group, compared to an increase from 8 percent to 28 percent in the control group. Girls in the experimental group also significantly improved their social skills.

- There was no impact on girls' perceptions of gender roles or self-esteem. Girls' mobility also remained limited; but parents of participating girls did allow them to attend group sessions and eventually, training outside the community, indicating that parental support is a key element of interventions to expand girls' life choices.

- Interest in vocational training was high. Of the 525 participants who completed the reproductive health course in the experimental area, 487 (93\%) took one course, and almost 80 percent completed two or more. The most popular courses were in henna painting $(56 \%)$, creative painting $(39 \%)$, pottery decoration (19\%), and tailoring (19\%). However, only 10 percent of girls were able to generate income from their new skills (see Figure).

- Social barriers impeded efforts to help girls improve their financial status. About 250 girls in the experimental area opened savings accounts at the local post office, but the male post office staff were often reluctant to provide service to the girls. Similarly, many girls who had attended vocational training said that they were unable to insist on payment for the products they made. Girls also reported that peers and friends failed to support their interest in having savings accounts.

\section{Course attendance and economic impact of skills classes for girls}



\section{Policy Implications}

- The study shows that interventions to improve girls' life skills are feasible. However, effecting significant improvements in girls' skills and economic advancement would require a longerterm intervention that nurtures skills while building relationships with parents and communities.

- Projects that include skill building should ensure that a local market exists for the items produced and that the courses are tailored to the interest of girls.

- The need for involvement of parents cannot be overemphasized. As decision-makers, parents need to be fully engaged in discussions of the importance of their daughters' schooling, livelihoods, and delayed marriage.

June 2005

Source: Sebastian, Mary P., Monica Grant, and Barbara Mensch. 2005. "Integrating adolescent livelihood activities within a reproductive health programme for urban slum dwellers in India," Population Council Final Report. New Delhi: Population Council. Available by e-mail fromfrontiers@pcdc.org.

This project was conducted with support from with support from the Mellon Foundation, the Department for International Development (DFID), UK, and the U.S. AGENCY FOR INTERNATIONAL DEVELOPMENT (USAID), under the terms of the Cooperative Agreements Number HRN-A-00-99-00010 and HRN-A-00-98-00012-00. 